\title{
Physicochemical Surface Properties and Phagocytosis by Polymorphonuclear Leucocytes of Different Serogroups of Salmonella
}

\author{
By JIANG HUI XIU, $†$ K.-E. MAGNUSSON, O. STENDAHL \\ AND L. EDEBO* $\ddagger$ \\ Department of Medical Microbiology, University of Linköping, 581-85 Linköping, Sweden
}

(Received 18 January 1983)

\begin{abstract}
Salmonella isolates belonging to different serogroups have been analysed with respect to physicochemical surface properties and interaction with human polymorphonuclear granulocytes (PMNs). Most (22/34) recent isolates of the different serotypes showed hydrophilic surface properties and little if any negative charge accompanied by resistance to phagocytosis by PMN similar to the old laboratory S strains Salmonella typhimurium 395MS and Salmonella minnesota S99 (main group). However, all isolates belonging to the serogroups C1 (5 isolates), E4 (2), $\mathrm{O} 43$ (1), and one out of three $\mathrm{E} 1$ isolates ( $\mathrm{C} 1 / \mathrm{E} 4$ group) differed from the main group. In aqueous biphasic partition in dextran-polyethyleneglycol (PEG) systems the bacteria in the main group accumulated in the PEG-rich phase to $55-97 \%$, those in the $\mathrm{C} 1 / \mathrm{E} 4$ group to less than $10 \%$, and R-mutants only to $1-2 \%$.

The bacteria in the $\mathrm{Cl} / \mathrm{E} 4$ group displayed a negative surface charge and a susceptibility to phagocytosis by PMNs that were greater than those for strains in the main group but much lower than those shown by the R-mutants. Bacteria belonging to serogroup $\mathrm{Cl}$ also displayed a significant susceptibility to hydrophobic interaction. The results are discussed in relation to the pathogenicity of salmonella.
\end{abstract}

\section{INTRODUCTION}

The structure of the outer membrane (Nikaido, 1980; Osborn \& Wu, 1980) and the surface properties (Edebo et al., 1980) of certain species of Salmonella like $S$. typhimurium and $S$. minnesota have been studied extensively in S strains and in different R-mutants. The S strains showed hydrophilic surface properties and little charge, whereas their R-mutants displayed more hydrophobic properties and negative charge. Furthermore the $\mathrm{S}$ strains were more resistant to phagocytosis by professional phagocytes (Stendahl \& Edebo, 1972) and were more virulent (Edebo \& Normann, 1970).

The genus Salmonella comprises approximately 2000 serotypes. The early serotypes were given Linnean binomial names related to disease such as $S$. typhi (human typhoid), S. choleraesuis (hog cholera), $S$. typhimurium (mouse typhoid), but later the host dependance of the pathogenicity of several species was shown to be broader. The pathogenicity of salmonella is dependent on the endotoxic properties of the lipid A portion of the outer membrane lipopolysaccharide (LPS), and on the structure of the $O$-antigenic polysaccharide chains peripheral to lipid A in the LPS which in some species have been shown to prevent phagocytosis and to

† Present address: Institute of Microbiology, Academia Sinica, Beijing, China.

$\ddagger$ Present address: Department of Clinical Bacteriology, University of Göteborg, 41346 Göteborg, Sweden.

Abbreviations: FITC, fluorescein isothiocyanate; HIC, hydrophobic interaction chromatography; IEC, ion exchange chromatography; PEG, polyethyleneglycol; P-PEG, palmitate-PEG; PMN, polymorphonuclear leucocytes; S-PEG, sulphonate-PEG; TMA-PEG, bistrimethylamino-PEG; TPP, two-phase partitioning. 
promote virulence. In addition to the $\mathrm{O}$ antigen, some strains, notably $S$. typhi, show the presence of $\mathrm{Vi}$ antigen at the surface. The $\mathrm{Vi}$ antigen, which is a highly polymerized acidic polysaccharide consisting of repeating units of $O$ - and $\mathrm{N}$-acetyl-D-galactosaminuric acid, also promotes virulence by preventing phagocytosis. Vi antigens closely related to that of $S$. typhi have been found in $S$. paratyphi $\mathrm{C}$ and in occasional strains of $S$. dublin. These antigens are closely related to the $\mathrm{K}$ antigens of Escherichia coli which also are acidic polysaccharides and prevent phagocytosis (Öhman et al., 1981).

In the genus Salmonella the base composition is $50-52 \mathrm{~mol} \% \mathrm{G}+\mathrm{C}$ and the strains (including arizona) are at least $70 \%$ related to each other as determined by DNA/DNA hybridization (Crosa et al., 1973). The metabolic properties which have been used for several years in the isolation and identification from clinical specimens are also similar. Also the antigenic surface structure is well established and extensively used for classification. Less is known about the physicochemical surface properties which may be related to pathogenicity in the different strains. This investigation has examined the physicochemical surface properties and phagocytosis of a representative selection of salmonella serotypes (species).

\section{METHODS}

Bacterial strains. Salmonella typhimurium 395MS and 395MR 10 (chemotype Rd) and S. minnesota S99 (S strain), R345 (chemotype Rb), R595 (chemotype Re) are laboratory strains that have been described elsewhere (Kihlström \& Magnusson, 1980). Thirty-four salmonella isolates recently cultured from clinical specimens were kindly supplied by Dr A. A. Lindberg (Swedish Salmonella reference laboratory, National Bacteriological Laboratory, Stockholm, Sweden).

Cultivation and radioactive labelling of bacteria. Bacteria were inoculated into $10 \mathrm{ml}$ glucose broth (glucose $1 \mathrm{~g}$, $\mathrm{Na}_{2} \mathrm{HPO}_{4} \cdot 2 \mathrm{H}_{2} \mathrm{O} 0.6 \mathrm{~g}, \mathrm{NaCl} 1.8 \mathrm{~g}$, peptone (Difco) $10 \mathrm{~g}$, beef extract (Difco) $5 \mathrm{~g}$, distilled water $1000 \mathrm{ml}$ ) containing $25 \mu \mathrm{L} \mathrm{L}-\left[{ }^{3} \mathrm{H}\right] l$ leucine (37 MBq ml${ }^{-1}$ NET-460; New England Nuclear), in $100 \mathrm{ml}$ bottles and were incubated on a rotary shaker at $37^{\circ} \mathrm{C}$ for $16 \mathrm{~h}$. Organisms were harvested by centrifugation $(4000 \mathrm{~g}, 10 \mathrm{~min})$ washed twice in saline buffer with $0.01 \mathrm{M}$-sodium phosphate (PBS, pH 7.3) and were suspended to $5 \times 10^{8}$ bacteria $\mathrm{ml}^{-1}$ in indicated buffers for testing the physicochemical surface properties.

Two-phase partitioning (TPP). The TPP system contained $4.4 \%(\mathrm{w} / \mathrm{w})$ PEG and $6.2 \%(\mathrm{w} / \mathrm{w})$ dextran T500 in $0.03 \mathrm{M}$-Tris buffer $\mathrm{pH} \mathrm{7.0.} \mathrm{This} \mathrm{mixture} \mathrm{was} \mathrm{prepared} \mathrm{in} \mathrm{a} \mathrm{separatory} \mathrm{funnel} \mathrm{from} \mathrm{stock} \mathrm{solutions} \mathrm{of} 20 \%$ ( $w / w$ ) PEG 6000 (Union Carbide, N.Y.), 20\% (w/w) dextran T500 (Pharmacia), $0 \cdot 1$ M-Tris buffer and distilled water. After mixing thoroughly the phases were allowed to separate at $4{ }^{\circ} \mathrm{C}$ overnight. The bottom phase and the top phase were collected separately. In order to analyse the charge and hydrophobicity of the bacterial surface, positively charged bistrimethylamino $\left[\left(\mathrm{CH}_{3}\right)_{3} \mathrm{~N}^{+}\right]$-PEG (TMA-PEG), negatively charged sulphonate $\left[\mathrm{SO}_{3}{ }^{-}\right]-$ PEG (S-PEG), and palmitate-PEG (P-PEG) were added to the systems (Kihlström \& Magnusson, 1980). The hydrophobic change of the partition of one strain, was calculated as the sum of the increase in the top phase and the decrease in the bottom phase (Kihlström \& Magnusson, 1980), and the significance estimated with a $t$-test with two degrees of freedom (Bailey, 1981).

For a TPP test, $2 \mathrm{ml}$ of bottom phase and $2 \mathrm{ml}$ of top phase were pipetted into graduated tubes and $0 \cdot 1 \mathrm{ml}$ bacterial suspension was added. The tubes were inverted 20 times for mixing and kept at $4{ }^{\circ} \mathrm{C}$ for $45 \mathrm{~min}$ to separate the phases. After recording the volumes of the bottom phase and the total system, $0.5 \mathrm{ml}$ samples were taken from each of the top and the bottom phase. The remainder was mixed, and another $0.5 \mathrm{ml}$ sample was taken. After dilution with $2 \mathrm{ml}$ water and addition of $5 \mathrm{ml}$ Aquasol, the radioactivity of the samples was counted in a beta-scintillation counter (Isocap 300, Searle-Nuclear Chicago, Ill., U.S.A.). The partition of bacteria was calculated from the volumes of the phases and the radioactivity (c.p.m.) of the samples from them.

Hydrophobic interaction chromatography (HIC). HIC was performed (Kihlström \& Magnusson, 1980) on OctylSepharose CL-4B (Pharmacia). A high ionic strength solution is desired as suspension medium in order to promote hydrophobic interaction. We employed an intermediate concentration, $0.35 \mathrm{M}-\left(\mathrm{NH}_{4}\right)_{2} \mathrm{SO}_{4}$ in a $0.01 \mathrm{M}$-sodium phosphate buffer, $\mathrm{pH} 7 \cdot 0$, to reduce the tendency of cells to aggregate. The Sepharose stock material was suspended in an equal volume of ammonium sulphate/phosphate buffer and $2 \mathrm{ml}$ was loaded into a Pasteur pipette. The height of the gel column was $4 \mathrm{~cm}$. After washing with the starting solution, $0 \cdot 1 \mathrm{ml}$ of the bacterial suspension was carefully added on top of the column. Elution was performed with successive $2 \mathrm{ml}$ volumes of

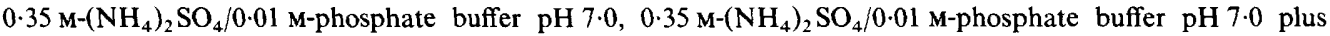
$0.1 \%$ Triton X-100, and $95 \%$ ethanol. A $0.5 \mathrm{ml}$ sample was taken from each eluate and mixed with $2 \mathrm{ml}$ water and $5 \mathrm{ml}$ Aquasol; c.p.m. values were determined with a beta-counter. As a control, a parallel test was run on a similar Sepharose CL-4B column.

Ion-exchange chromatography (IEC). IEC on DEAE-Sephacel (Pharmacia) was performed (Kihlström \& 
Magnusson, 1980) in a manner similar to HIC in Pasteur pipettes. A volume of $0.1 \mathrm{ml}$ bacteria suspended in $0 \cdot 15 \mathrm{M}-\mathrm{NaCl} / 0 \cdot 01 \mathrm{M}$-sodium phosphate buffer $\mathrm{pH} 7 \cdot 0$, was loaded on to the column. Elution was done with $2 \mathrm{ml}$ volumes of increasing salt concentrations: $0 \cdot 15 \mathrm{M}-\mathrm{NaCl}, 2 \cdot 1 \mathrm{M}-\mathrm{NaCl}$ and $4 \cdot 1 \mathrm{M}-\mathrm{NaCl}$. Eluates were processed as above for beta-counting.

Phagocytosis. Phagocytosis was tested in vitro by adding fluorescein isothiocyanate (FITC)-labelled bacteria to monolayers of human polymorphonuclear leucocytes (PMN) and observing the cells in a combined phase-contrast and UV-epifluorescence microscope (Hed, 1977). For FITC-labelling, bacteria $\left(2.5 \times 10^{9} \mathrm{ml}^{-1}\right)$ were suspended in $0.2 \mathrm{M}$-sodium carbonate-bicarbonate buffer, $\mathrm{pH} 9.5$, mixed with FITC-solution $\left(1.5 \mathrm{mg} \mathrm{ml}^{-1}\right.$ in the same buffer), and kept at room temperature for $30 \mathrm{~min}$. After washing twice with PBS and once with Krebs-Ringer

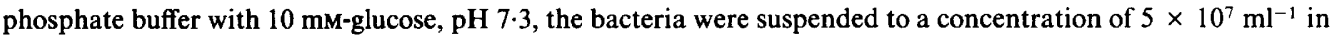
Krebs-Ringer buffer. Freshly taken human blood dropped directly from the finger-tip on to a microscopic slide was the source of PMNs. After $30 \mathrm{~min}$ at $37^{\circ} \mathrm{C}$ the blood clot was rinsed away, $0 \cdot 1 \mathrm{ml}$ of the bacterial suspension $\left(5 \times 10^{7} \mathrm{ml}^{-1}\right)$ added, and the slide incubated for $1 \mathrm{~h}$ at $37^{\circ} \mathrm{C}$.

Fluorescence quenching of non-ingested bacteria with crystal violet $\left(0.8 \mathrm{mg} \mathrm{ml}{ }^{-1}\right)$ was used to discriminate between extracellular and intracellular bacteria. One hundred PMNs were observed and the total number of associated (observed in the absence of crystal violet) and ingested (observed with crystal violet) bacteria in conjunction with each PMN, was counted. It was noted that extracellular salmonella S-type bacteria were less easily quenched than R-type bacteria. After heat-killing the extinction of the fluorescence was more complete.

Haemagglutination by bacteria. The presence of type 1 fimbriae and P-fimbriae was tested for by agglutination of guinea-pig and human erythrocytes, respectively (Duguid \& Old, 1980; Öhman et al., 1982). From a suspension of erythrocytes $1.5 \%(\mathrm{v} / \mathrm{v})$ in PBS, $\mathrm{pH} 7 \cdot 3,75 \mu \mathrm{l}$ was mixed with $25 \mu \mathrm{l}$ bacteria $\left(1.2 \times 10^{9} \mathrm{ml}^{-1}\right)$ in microtiter plates and rocked gently for $45 \mathrm{~min}$ at room temperature. Haemagglutination was observed with the naked eye.

\section{RESULTS}

\section{Partition in dextran-PEG two-phase systems}

In the basic dextran-PEG system without substituted PEG, R-mutants accumulated mainly at the interface and in the bottom phase (Table 1$)$ such that very few organisms $(1-2 \%)$ appeared in the top phase (Fig. 1). In contrast, most $(24 / 36)$ of the clinical isolates were found mainly (55$98 \%$ ) in the top phase (Fig. 1). However, some of the clinical isolates showed less than $10 \%$ partition into the top phase. Partition to the bottom phase consistently appeared in certain serogroups, viz. in all of five serogroup $\mathrm{C} 1$ isolates, the two $\mathrm{E} 4$ isolates, and the one $S$. houten $(\mathrm{O} 43)$, isolate tested. One out of three serogroup $\mathrm{E} 1$ isolates ( $S$. muenster) also showed this type of partition. This group is called the C1/E4 group. Two out of seven serogroup B isolates, and one serogroup $\mathrm{K}$ isolate ( $S$. cerro), showed intermediate partition into the top phase (i.e. between 25 and $36 \%$ ).

Addition of positively charged TMA-PEG changed the partition of R-mutants from the bottom phase and interface towards the top phase (Table 1), indicating a predominantly negative surface charge. In contrast, little change of partition was observed with the laboratory $S$ strains and most of the clinical isolates. A small effect of TMA-PEG was observed on some strains particularly on those belonging to the $\mathrm{C} 1 / \mathrm{E} 4$ group. When the significance of the change of partition by TMA-PEG was calculated for the individual isolates by Student's $t$-distribution with two degrees of freedom (Bailey, 1981) the significance was rarely greater than $P<0.05$ but a clustering of significant values appeared in the $\mathrm{Cl} / \mathrm{E} 4$ group. Thus, when the substitution by TMA-PEG was calculated as the sum of the increase in the top phase and the decrease in the bottom phase, the $\mathrm{C} 1 / \mathrm{E} 4$ showed a difference of $16.3 \%$ ( \pm 0.76 S.E.M.), whereas the remaining $\mathrm{S}$ strains (main group) differed by only $2 \cdot 2 \%( \pm 2 \cdot 1$ S.E.M.). The difference in response of these two groups of strains was highly significant $(P<0.001)$ as tested with a $t$-test (Bailey, 1981).

For most strains negatively charged S-PEG had no effect on partition though some effect was observed with individual isolates. When the effect was calculated as the sum of increase in top phase and decrease in bottom phase the effect on the C1/E4 group $(8.6 \% \pm 1.9$ S.E.M.) was not significantly different from that on the main group $(6.0 \% \pm 1.4$ S.E.M.). The effect of P-PEG was greater on the $\mathrm{Cl} / \mathrm{E} 4$ group $(9.3 \% \pm 2.3$ S.E.M.) than on the main group ( $3.6 \% \pm 1.4$ S.E.M.). However, the difference was barely significant $(P \approx 0.05)$. The difference was highly significant $(P<0.001)$ when only the $C 1$ strains were grouped $(13.5 \% \pm 1.5$ S.E.M.). The effect of P-PEG was still greater on the R-mutants with the most incomplete LPS. 


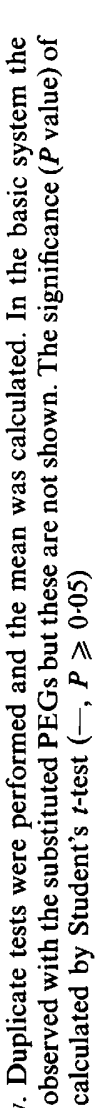

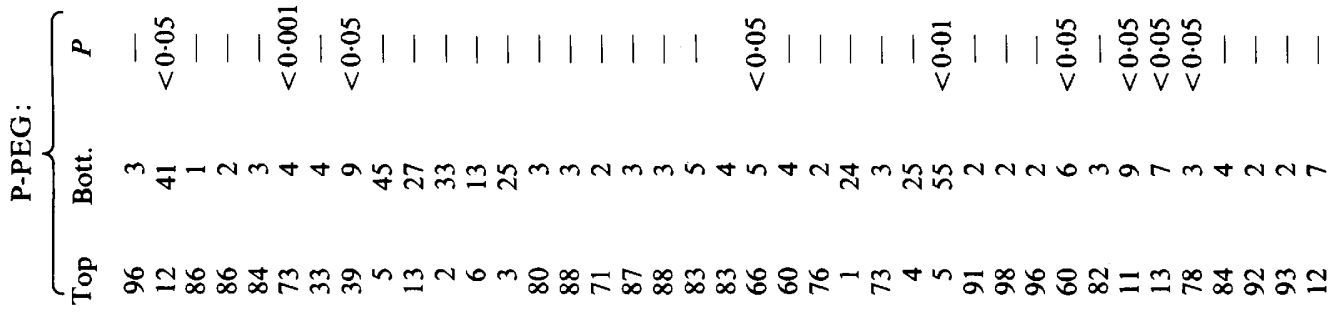

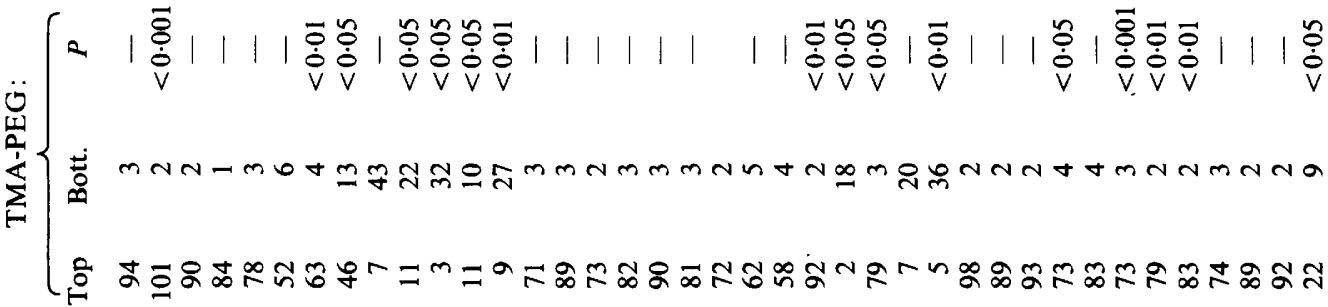

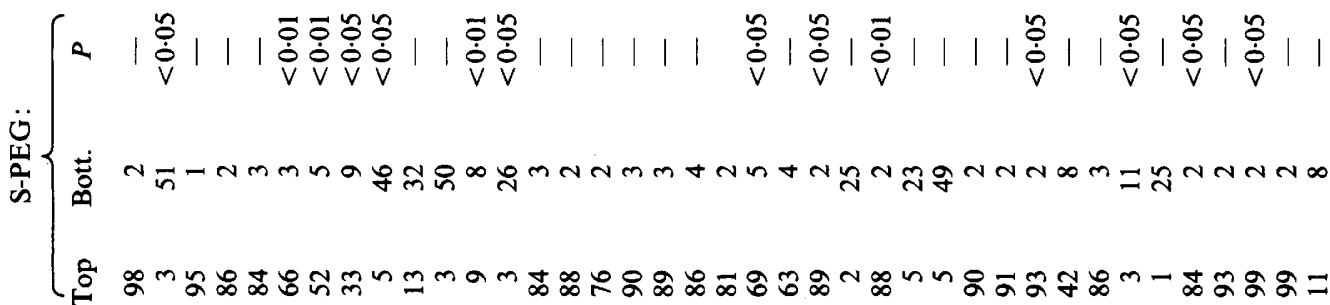

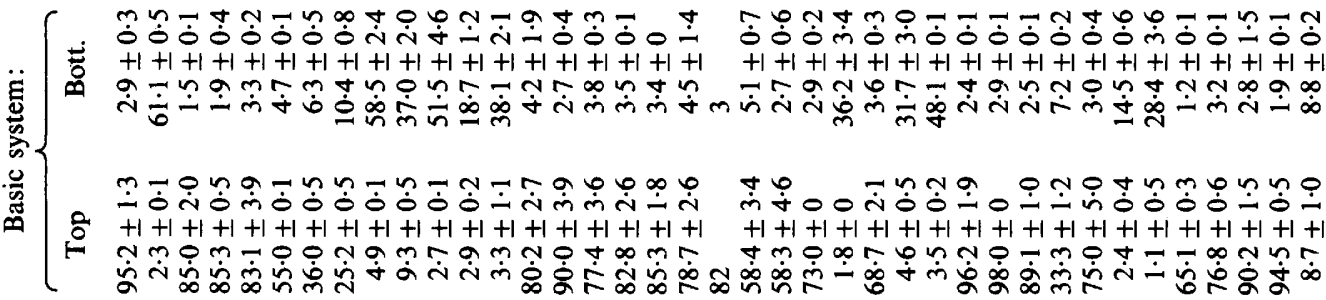

을

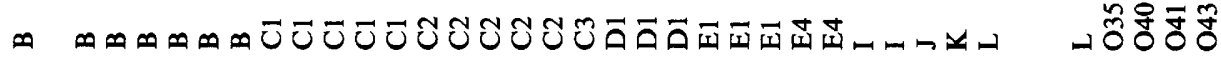

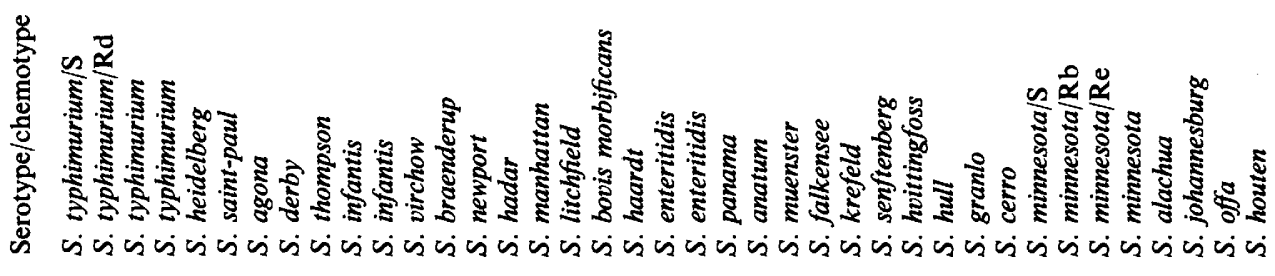

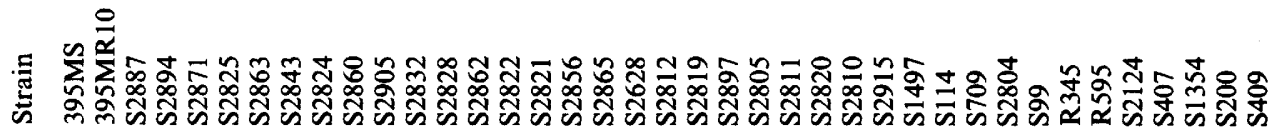




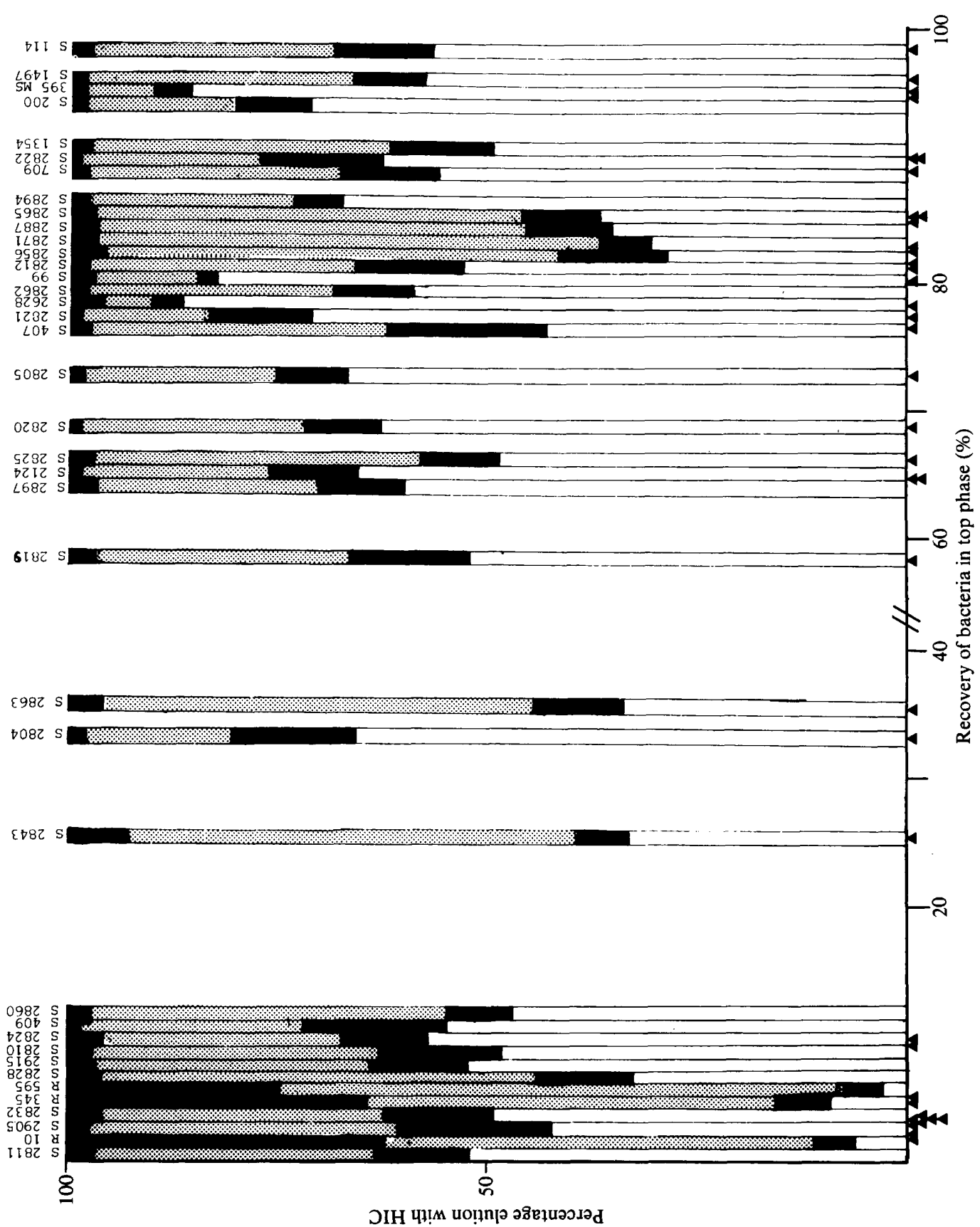

Fig. 1. Hydrophobic interaction chromatography on Octyl-Sepharose in relation to partition into the top phase in the basic dextran-PEG two-phase system. Each strain (isolate) is represented as a bar. Percentage elution from Octyl-Sepharose is shown as bars (the first elution step, open bar; the second elution step, filled bar; the third elution step, stippled bar and the fourth elution step, filled bar). The strains (isolates) are ranked according to recovery in the top phase (shown at the top of the diagram by the strain number). The exact positions of overlapping bars are shown by triangles below the abscissa. 
Table 2. Chromatography of salmonella on DEAE-Sephacel (ion exchange) and Sepharose CL-4B (control)

For the individual strains/isolates the duplicate tests were performed and the mean was calculated. For the DEAE-Sephacel data the \pm values indicate ranges about the mean. Similar ranges were observed with Sepharose CL-4B, but these are not shown. The bacteria in the serogroups C1, E4 and O43, plus the $S$. muenster (E1) strain were grouped together, and the mean and S.D. calculated. The radioactivity is given as the sum in per cent of the added radioactivity.

S. typhimurium 395MS

S. minnesota $\mathbf{S 9 9}$

S. typhimurium 395MR10

S. minnesota R345

S. minnesota R595

S. agona (B)

S. derby (B)

S. cerro (K)

Serogroup C1, E4, O43 and

$S$. muenster (E1) (9 isolates)
DEAE-Sephacel

\begin{tabular}{|c|c|c|c|c|}
\hline \multicolumn{5}{|c|}{ DEAE-Sephacel } \\
\hline \multicolumn{4}{|c|}{ Radioactivity $(\%)$ in elution step: } & \multirow{2}{*}{$\begin{array}{c}\text { Recovery } \\
(\%)\end{array}$} \\
\hline 1 & 2 & 3 & 4 & \\
\hline $77 \cdot 0 \pm 1 \cdot 8$ & $17 \cdot 1 \pm 1 \cdot 7$ & $1.8 \pm 0.3$ & $4 \cdot 1 \pm 0 \cdot 1$ & $90 \pm 2$ \\
\hline $71 \cdot 3 \pm 1 \cdot 9$ & $21 \cdot 7 \pm 2 \cdot 1$ & $2 \cdot 5 \pm 0 \cdot 3$ & $4 \cdot 4 \pm 0 \cdot 1$ & $84 \pm 3$ \\
\hline $0 \cdot 8 \pm 0 \cdot 1$ & $33 \cdot 5 \pm 1 \cdot 8$ & $5 \cdot 7 \pm 0 \cdot 1$ & $60 \cdot 1 \pm 1 \cdot 8$ & $73 \pm 0$ \\
\hline $1.5 \pm 0.9$ & $43 \cdot 5 \pm 2 \cdot 7$ & $4.5 \pm 0.9$ & $50 \cdot 5 \pm 2 \cdot 8$ & $73 \pm 2$ \\
\hline $1 \cdot 3 \pm 0 \cdot 1$ & $27 \cdot 0 \pm 3 \cdot 4$ & $7 \cdot 5 \pm 1 \cdot 8$ & $64 \cdot 2 \pm 4 \cdot 8$ & $73 \pm 5$ \\
\hline $65 \cdot 0 \pm 2 \cdot 4$ & $26 \cdot 0 \pm 1 \cdot 4$ & $3 \cdot 0 \pm 1 \cdot 3$ & $6.0 \pm 0.6$ & $79 \pm 1$ \\
\hline $58 \cdot 4 \pm 1 \cdot 3$ & $21 \cdot 4 \pm 0.3$ & $3.6 \pm 0.4$ & $16.6 \pm 0.6$ & $66 \pm 2$ \\
\hline $61 \cdot 2 \pm 1 \cdot 1$ & $22 \cdot 0 \pm 0.6$ & $4 \cdot 0 \pm 0.6$ & $12 \cdot 7 \pm 0 \cdot 1$ & $82 \pm 0$ \\
\hline $62 \cdot 1 \pm 8 \cdot 5$ & $21 \cdot 6 \pm 6 \cdot 3$ & $4 \cdot 2 \pm 1 \cdot 5$ & $12 \cdot 1 \pm 4 \cdot 5$ & $79 \cdot 4 \pm 7 \cdot 0$ \\
\hline
\end{tabular}

\section{Sepharose CL-4B}

\begin{tabular}{|c|c|c|c|c|}
\hline \multicolumn{5}{|c|}{ Sepharose CL-4B } \\
\hline \multicolumn{4}{|c|}{ Radioactivity ( $\%$ ) in elution step: } & \multirow{2}{*}{$\begin{array}{c}\text { Recovery } \\
(\%)\end{array}$} \\
\hline - 1 & 2 & 3 & 4 & \\
\hline 95 & 4 & 1 & 0 & 89 \\
\hline 86 & 12 & 1 & 1 & 84 \\
\hline 40 & 44 & 4 & 11 & 80 \\
\hline 18 & 49 & 15 & 19 & 80 \\
\hline 27 & 39 & 25 & 9 & 68 \\
\hline 63 & 33 & 3 & 1 & 88 \\
\hline 38 & 55 & 5 & 2 & 80 \\
\hline 59 & 39 & 2 & 1 & 93 \\
\hline $50 \cdot 5 \pm 8 \cdot 6$ & $43 \cdot 5 \pm 7 \cdot 7$ & $4 \cdot 4 \pm 1 \cdot 4$ & $1 \cdot 6 \pm 1 \cdot 0$ & $84 \pm 4$ \\
\hline
\end{tabular}

S. typhimurium 395MS

S. minnesota $\mathrm{S} 99$

S. typhimurium 395MR10

S. minnesota $\mathrm{R} 345$

S. minnesota R595

S. agona (B)

S. derby (B)

S. cerro (K)

Serogroup C1, E4, O43 and

$S$. muenster (E1) (9 isolates)

\section{Hydrophobic interaction chromatography on Octyl-Sepharose}

After chromatography on Octyl-Sepharose recovery of the R-mutants R10, R345 and R595 was very low in the first (3.4-9.2\%) and second (3.8-6.3\%) eluting steps; most of the organisms $(49-68 \%)$ were recovered after elution with ethanol, although a substantial proportion $(25-37 \%)$ remained in the column after elution (Fig. 1). In control experiments in which these strains were passed through Sepharose CL-4B columns, most of the bacteria (66-85\%) were recovered in the first two elution steps (Table 2); thus the hydrophobic interaction of the R-mutants was great. In contrast the two laboratory S strains $S$. typhimurium $395 \mathrm{MS}$ and $S$. minnesota S99 showed little if any interaction, since these strains eluted with yields of $86 \%$ and $82 \%$, respectively, from OctylSepharose in elution step 1 (Fig. 1). Control tests on Sepharose CL-4B gave $95 \%$ and $86 \%$ elution of these strains in elution step 1 (Table 2). Another isolate, S2628 ( $S$. haardt) which yielded $87 \%$ in the first elution step from Octyl-Sepharose (Fig. 1), is not considered here because this value was larger than the yield from Sepharose CL-4B (67\%).

For the remaining clinical isolates the yield in the first elution step contained $29-71 \%$ (Fig. 1); these values were little different from the control tests on Sepharose CL-4B. The yield from the second elution step after addition of another $2 \mathrm{ml}$ buffer was, however, conspicuously lower after chromatography on Octyl-Sepharose (4-19\%, mean \pm S.D. $=11.0 \pm 3 \cdot 2)$ than on Sepharose CL-4B (15-58\%, mean \pm S.D. $=36 \cdot 1 \pm 10 \cdot 4)$. The combined totals of the first two elution steps ranged from $36-83 \%$ (mean \pm S.D. $=62.7 \pm 12.6)$ on Octyl-Sepharose, and from $73-98 \%$ 


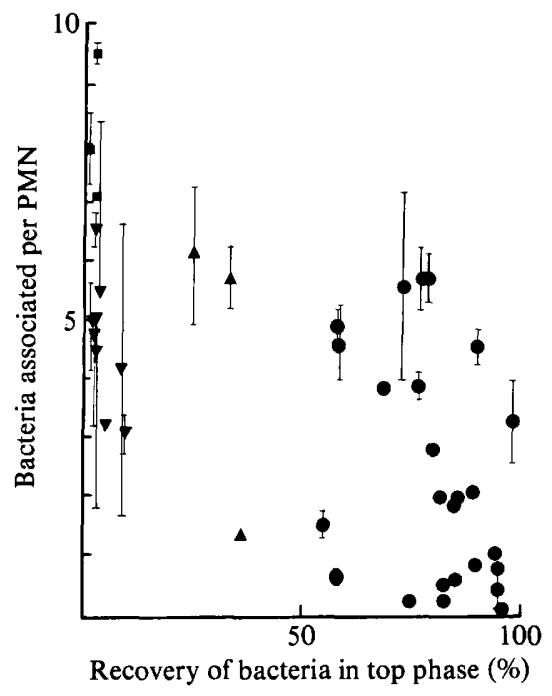

Fig. 2

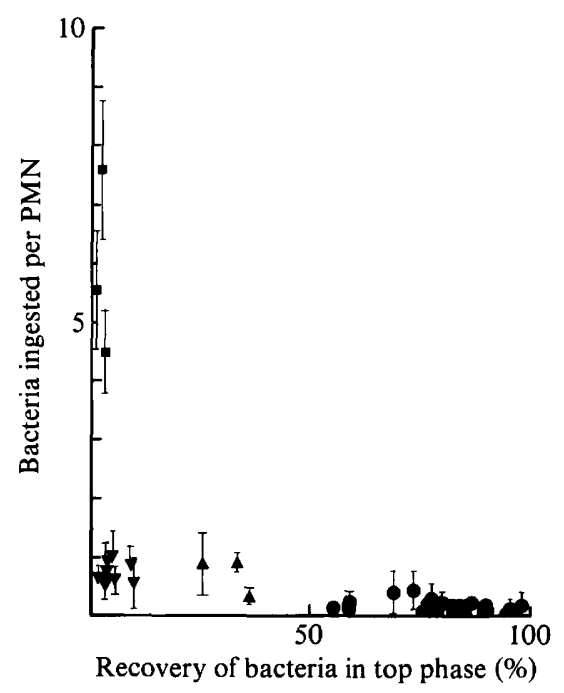

Fig. 3

Fig. 2. Number of bacteria associated per PMN (extracellular + intracellular) in relation to the partition of the bacteria into the top phase of the basic dextran-PEG two-phase system. $\square$, R-mutants; $\boldsymbol{\nabla}$, the C1/E4 group, i.e. serogroups C1, E4 and O43 and S. muenster S2811 (E1); $\Delta, S$. agona S2863 (B), $S$. derby $\mathrm{S} 2843(\mathrm{~B})$, and $S$. cerro $\mathrm{S} 2804(\mathrm{~K}) ; 0$, the old laboratory $\mathrm{S}$ strains and remaining clinical isolates. The vertical bars join duplicate determinations. When no bar appears the two determinations are within the area of the symbol.

Fig. 3. Number of bacteria ingested per PMN versus the partition into the top phase. Symbols as for Fig. 2.

(mean \pm S.D. $=92.3 \pm 4.9$ ) on Sepharose CL-4B indicating a small hydrophobic interaction. For the C1/E4 group the sums of the first two fractions on Octyl-Sepharose was $44-72 \%$ (mean \pm S.D. $=60.9 \pm 7.5$ ) not significantly different from the main group.

\section{Ion exchange chromatography}

When bacterial suspensions were passed through DEAE-Sephacel columns, recovery of the R-mutants in the first elution step was only $0.8-1.5 \%$ (Table 2 ), whereas the corresponding value for $\mathrm{S}$ bacteria and clinical isolates ranged from $48-82 \%$ (S. litchfield, $26 \%$, and S. alachua, $39 \%$, were exceptions). However, an unusually large yield was obtained in the second elution step, indicating only minor retardation. After elution with $4 \cdot 1 \mathrm{M}-\mathrm{NaCl} 51-64 \%$ of the R-mutants remained in the gel, whereas the corresponding fraction of S bacteria was 4-28\%; again $S$. litchfield $(28 \%)$ and $S$. alachua $(21 \%)$ were two of the three strains showing the greatest retention in the column. The different groups of $\mathrm{S}$ strains and clinical isolates showed considerable overlapping around slightly different means (Table 2). In summary the order with respect to free flow (non-retention) on DEAE-Sephacel was: laboratory $\mathrm{S}$ strains $>$ most clinical isolates $>S$. agona, $S$. derby, $S$. cerro $>$ group $\mathrm{Cl} / \mathrm{E} 4 \gg$ laboratory $\mathrm{R}$-mutants. In all groups retention was greater by DEAE-Sephacel than by Sepharose CL-4B.

\section{Association with PMN}

The three R-mutants showed extensive association with the PMNs giving a range of 7.1-9.5 organisms per PMN (Fig. 2), and 63-80\% of these, i.e. $4 \cdot 5-7 \cdot 6$ bacteria per PMN were ingested (Fig. 3). The association of the laboratory $\mathrm{S}$ strains and the clinical isolates showed great differences among the strains. Values ranged from 0.15-6.6 bacteria per PMN, with only few organisms being ingested $(2 \cdot 5-20 \%)$. The nine isolates of the $\mathrm{Cl} / \mathrm{E} 4$ group, which were not 
recovered from the top phase in a dextran-PEG two-phase system (Fig. 3), were more liable to phagocytosis than 24 strains for which recovery in the top phase was more than $50 \%$. Calculated according to Wilcoxon's rank sum test this difference is highly significant $(P<0.001)$.

\section{Haemagglutination test for fimbriae}

Among 16 strains tested (all C1, E4 and O43 strains) none agglutinated human erythrocytes, indicating absence of P-fimbriae. Only $S$. krefeld showed weak agglutination with guinea-pig erythrocytes. Thus, under the growth conditions used in the present experiments neither type 1 fimbriae were detected by haemagglutination (Duguid \& Old, 1980).

\section{DISCUSSION}

As found previously (Edebo et al., 1980; Kihlström \& Magnusson, 1980) the laboratory S strains $S$. typhimurium 395MS and $S$. minnesota $\$ 99$ showed hydrophilic properties and absence of ionized groups, whereas the R-mutants $S$. typhimurium 395MR10, $S$. minnesota R345 and $S$. minnesota $\mathrm{R} 595$ demonstrated hydrophobic properties and negative charge. The present experiments included chromatography on Sepharose CL-4B as a control for interaction with the dextran matrix. Some retardation was observed with the R-mutants on the control gel, but there was a considerable increase in the retention of the R-mutants on Octyl-Sepharose CL-4B and on DEAE-Sephacel, so binding to the hydrophobic and positively charged groups, respectively, appeared significant. Aggregation of the $\mathrm{R}$ bacteria in $0.3 \mathrm{M}-\left(\mathrm{NH}_{4}\right)_{2} \mathrm{SO}_{4}$ or weak interaction with the Sepharose beads might have contributed to retardation in the Sepharose CL-4B column.

Most of the clinical isolates behaved like the laboratory $\mathrm{S}$ strains in all partition and chromatography tests. However, isolates belonging to the serogroups $\mathrm{C} 1$ and $\mathrm{E} 4$ (the $\mathrm{C1} / \mathrm{E} 4$ group), did not conform to this pattern. They accumulated in the bottom phase in the dextranPEG two-phase system like $R$ bacteria but differed from them in being less influenced by TMAPEG and P-PEG. No such differences among the clinical isolates were evident in the interaction with Octyl-Sepharose CL-4B and DEAE-Sephacel. The surface structure(s) responsible for the behaviour in phase partition is not known. The similar partition of bacteria and LPS (Edebo et al., 1980) and the agreement among the five serogroup $\mathrm{Cl}$ isolates suggest that the chemical nature of the LPS is responsible. This may also be the case for the two serogroup E4 isolates and $S$. houten $\mathrm{S} 409$ (O43). However, differences in partition within the serogroups $\mathrm{E} 1$ and B demonstrate that the immunochemical properties of the LPS is not the sole determinant of the physicochemical surface properties. Chromatography of the clinical isolates on Octyl-Sepharose showed some retardation compared to the laboratory strains $S$. typhimurium $395 \mathrm{MS}$ and $S$. minnesota S99. This retardation was greater than on Sepharose CL-4B. Several of the clinical isolates also associated more avidly with PMNs than the laboratory $\mathrm{S}$ strains indicating that adhesive surface structures may be exposed. Öhman et al. $(1981,1982)$ recently showed that increased affinity of $E$. coli strains for Octyl-Sepharose correlated with increased exposure of hydrophobic type 1 fimbriae. Although haemagglutination experiments did not detect any type 1 fimbriae under our experimental conditions, it cannot be ruled out that adhesive structures of this kind may be present in our clinical isolates, since Duguid et al. (1976) found that $85 \%$ of strains of $S$. typhimurium from natural sources contained these structures. Quantitative differences with respect to fimbriae, LPS and O-antigenic determinant polymerization as well as additional outer membrane proteins may affect the results of several of the tests performed (Stendahl et al., 1973a,b).

The virulence of $S$. typhimurium after injection into mice is dependent on the mouse strain (Hormaeche, 1979; Plant \& Glynn, 1982) and the quantity of the $S(O)$-antigen repeat unit of the bacteria (Edebo \& Normann, 1970). Larger quantities of S-antigen also correlate with hydrophilic surface properties and absence of charge (Edebo et al., 1980) and with resistance to phagocytosis (Stendahl \& Edebo, 1972).

The virulence of different salmonella serogroups and serotypes has been elegantly investigated in genetic transfer experiments by Mäkelä, Valtonen and coworkers. Isogenic 
transductants with the $\mathrm{O}$-antigen $1,4,12$, were most virulent. Bacteria with the $\mathrm{O}$-antigen $1,9,12$, were less virulent and bacteria with the O-antigen 6,7, were nearly avirulent (Mäkelä et al., 1973; Valtonen, 1970; Valtonen et al., 1975). Also three fresh human faecal isolates of salmonella group $\mathrm{C}(\mathrm{O}-6,7)$ were completely avirulent $\left(\mathrm{LD}_{50}>10^{7}\right.$; Valtonen, 1977$)$ for the mice. These results showed that the chemical composition of the S-specific repeating carbohydrate portion is of great importance for virulence. In contrast, mutations in S. typhimurium leading to loss of two major outer membrane proteins did not change the virulence (Valtonen $e t$ al., 1977). Salmonella typhimurium hybrid strains containing 0-6,7 antigen were cleared more rapidly from the blood than 0-4,12 sister hybrids (Valtonen, 1977) and phagocytosed more rapidly by a macrophage-like cell line in vitro in a complement-dependent process (LiangTakasaki et al., 1982). Our experiments showed that, in the absence of complement the ingestion by PMNs of the clinical isolates of the $0-6,7$ bacteria was significantly greater than that of the main group. Furthermore, these bacteria were more liable to hydrophobic interaction with $P$ PEG. The chemical composition of the 0-6,7 LPS is notably different from that of other serogroups of salmonella (Lindberg \& Le Minor, 1983). It contains mainly mannose polymerized in $1 \rightarrow 2$ linkages. This polysaccharide might expose an area deficient in hydroxyl groups with increased liability to hydrophobic interaction.

The above results indicate that qualitative differences between the LPS of different serogroups influence the pathogenicity. Little data comparing the pathogenicity of different species (serotypes) is, however, available. In a classical paper on the taxonomy of salmonella, Kaufmann (1930) examined the oral pathogenicity for mice. Three species that showed oral pathogenicity for mice in his investigation accumulated in the top phase $(58-95 \%$, mean $=81$, S.D. $\pm 11, n=6$ ) of our dextran-PEG two-phase system, whereas three species that did not kill the mice were not recovered from the top phase (3-5\%, mean 3.8, S.D. $\pm 0 \cdot 8, n=3$ ). This correlation is, however, not significant $(P=0 \cdot 1)$. Neither were all isolates of serogroup $\mathrm{C} 1$ nonpathogenic for mice. In different oral feeding experiments of rats $S$. oranienburg $(6,7: \mathrm{m}, \mathrm{t}:-)$, showed no difference to four other salmonella serotypes including $S$. typhimurium (Ruitenberg $e t$ al., 1971). Thus, the relationship between LPS structure and pathogenicity is equivocal. The increase in virulence for chicken and mice on converting the $\mathrm{O}$ antigen of $S$. cholerae-suis from 6,7 to 6,7 by phage may be involved (Smith \& Parsell, 1974). Properties affecting the multiplication within the host, like defects in the synthesis of thymine, aromatic amino acids and enterochelin as well as attachment fimbriae and the enterobacterial common antigen are also known to influence the virulence (Lindberg, 1980). With the exceptions of $S$. typhi and $S$. paratyphi A-C most salmonellae are considered to cause mild enteritis in general. For a long time the serological response in $S$. typhi and $S$. paratyphi infections has been recognized, e.g. by bacterial agglutination tests. When more sensitive serological methods were used to study a food-borne epidemic with $S$. enteritidis, there was a regular, time-dependent antibody response (Edebo et al., 1981) indicating that the bacteria or their LPS penetrated far enough to stimulate the immunological apparatus even in the mild cases. Salmonella enteritidis showed hydrophilic surface properties and resistance to phagocytosis. No data are as yet available about the human antibody response to the $\mathrm{C} 1 / \mathrm{E} 4$ group to support further differences in pathogenicity.

This work was supported by a generous grant from the Sven and Dagmar Salén Foundation and from the Swedish Medical Research Council (Project 2183).

\section{REFERENCES}

BaIley, N. T. J. (1981). Statistical Methods in Biology. London: Hodder \& Stoughton.

Crosa, J. F., Brenner, D. J., Ewing, W. H. \& FALKow, S. (1973). Molecular relationships among the Salmonellae. Journal of Bacteriology 115, 307315.

Duguid, J. P. \& Old, D. C. (1980). Adhesive properties in Enterobacteriaceae. Bacterial Adher- ence (Receptors and Recognition, series B, vol. 6), pp. 185-217. Edited by E. H. Beachey. London: Chapman \& Hall.

Duguid, J. P., Darekar, M. R. \& Wheater, D. W. F. (1976). Fimbriae and infectivity in Salmonella typhimurium. Journal of Medical Microbiology 9, 459473.

Edebo, L. \& NormanN, B. (1970). Virulence and 
immunogenicity of mutant strains of Salmonella typhimurium. Acta pathologica et microbiologica scandinavica 78B, 75-84.

Edebo, L., Kihlström, E., Magnusson, K.-E. \& STENDAHL, O. (1980). The hydrophobic effect and charge effects in the adhesion of enterobacteria to animal cell surfaces and the influence of antibodies of different immunoglobulin classes. In Cell Adhesion and Motility (Third Symposium of the British Society for Cell Biology), pp. 65-101. Edited by A. S. G. Curtis \& J. D. Pitts. Cambridge: Cambridge University Press.

Edebo, L., Nilsson, B.-O., Lindberg, A. A., Svenungsson, B. \& CoOMBS, R. R. A. (1981). Class of serum antibodies towards Salmonella enteritidis in gastro-enteritis, as measured by mixed reverse passive antiglobulin haemmagglutination (MRPAH). Acta pathologica et microbiologica scandinavica 89B, 341-346.

HED, J. (1977). The extinction of fluorescence by crystal violet and its use to differentiate between attached and ingested microorganisms in phagocytosis. FEMS Microbiology Letters 1, 357-361.

HORMAECHE, C. E. (1979). Natural resistance to Salmonella typhimurium in different inbred mouse strains. Immunology 37, 311-318.

Kauffmann, F. (1930). Die Technik Typhus-Paratyphusgruppe er Typenbestimmung in der Zentralblatt für Bakteriologie, Parasitenkunde und Infektionskrankheiten (Abteilung I, Originale A) 119, 152-160.

KiHLSTRÖM, E. \& MAGNUSSON, K.-E. (1980). Association with HeLa cells of LPS mutants of Salmonella typhimurium and Salmonella minnesota in relation to their physicochemical surface properties. Cell Biophysics 2, 177-189.

Liang-Takasaki, C.-J., Mäkelä, P. H. \& Leive, L. (1982). Phagocytosis of bacteria by macrophages: Changing the carbohydrate of lipopolysaccharide alters interaction with complement and macrophages. Journal of Immunology 128, 1229-1235.

LINDBERG, A. A. (1980). Bacterial virulence factors with particular reference to Salmonella bacteria. Scandinavian Journal of Infectious Diseases (supplement) 24, 86-92.

LINDBERG, A. A. \& LE MINOR, L. (1983). Serology of Salmonella. In Methods in Microbiology (in the Press).

MÄKELÄ, P. H., VALTONEN, M. V. \& VALTONEN, V. V. (1973). Role of O-antigen (lipopolysaccharide) factors in the virulence of Salmonella. Journal of Infectious Diseases (supplement) 128, 81-85.

Nikaido, H. (1980). Nonspecific transport through the outer membrane. In Bacterial Outer Membranes, Biogenesis and Functions, pp. 361-409. Edited by M. Inouy. New York: Wiley.

Öhman, L., NormanN, B. \& Stendahl, O. (1981). Physicochemical surface properties of Escherichia coli strains isolated from different types of urinary tract infections. Infection and Immunity 32, 951-955.

Öhman, L., Magnusson, K.-E. \& Stendahl, O. (1982). The mannose-specific lectin activity of Escherichia coli type 1 fimbriae assayed by agglutination of glycolipid-containing liposomes, erythrocytes, and yeast cells and hydrophobic interaction chromatography. FEMS Microbiology Letters 14, 149-153.

Osborn, M. J. \& WU, H. C. P. (1980). Proteins of the outer membrane of gram-negative bacteria. Annual Review of Microbiology 34, 369-422.

Plant, J. E. \& GlYNN, A. A. (1982). Genetic control of resistance to Salmonella typhimurium infection in high and low antibody responder mice. Clinical and Experimental Immunology 50, 283-290.

RUitenberG, E. J., KaMPelmaCheR, E. H. \& VAN NoORLE JANSEN, M. (1971). Effect of the method of administration on the invasive capacity of Salmonella. Zentralblatt für Bakteriologie (Originale A) 219, 336-347.

Smith, H. W. \& Parsell, Z. (1971). The effect on virulence of converting the $\mathrm{O}$ antigen of Salmonella cholerae-suis from $6_{2} 7$ to $6_{1} 7$ by phage. Journal of General Microbiology 81, 217-224.

Stendahl, O. \& EDebo, L. (1972). Phagocytosis of mutants of Salmonella typhimurium by rabbit polymorphonuclear cells. Acta pathologica et microbiologica scandinavica 80B, 481-488.

Stendahl, O., Magnusson, K.-E., Tagesson, C., Cunningham, R. \& Edebo, L. (1973a). Characterization of mutants of Salmonella typhimurium by counter-current distribution in an aqueous twopolymer phase system. Infection and Immunity 7, 573-577.

Stendahl, O., Tagesson, C. \& Edebo, M. (1973b). Partition of Salmonella typhimurium in a twopolymer aqueous system in relation to liability to phagocytosis. Infection and Immunity 8, 36-41.

VALTONEN, M. V. (1977). Role of phagocytosis in mouse virulence of Salmonella typhimurium recombinants with $\mathrm{O}$ antigen 6,7 or 4,12 . Infection and Immunity 18, 574-582.

Valtonen, M. V., Plosila, M., Valtonen, V. V. \& MÄKELÄ, P. H. (1975). Effect of the quality of the lipopolysaccharide on mouse virulence of Salmonella enteritidis. Infection and Immunity 12, 828-832.

VAltonen, M. V., Nurminen, M., Johansson, V. \& MÄKELÄ, P. H. (1977). Mouse virulence of Salmonella typhimurium mutants deficient in two major outer membrane proteins. Infection and Immunity 18, 454-458.

VALTONEN, V. V. (1970). Mouse virulence of Salmonella strains: the effect of different smooth-type $O$ side chains. Journal of General Microbiology 64, 255-268. 